\title{
Patterns of nocturnal movement of the long-spined sea urchin Diadema antillarum (Philippi) in Gran Canaria (the Canary Islands, central East Atlantic Ocean)
}

Received: 17 February 2003 / Revised: 25 August 2003 / Accepted: 28 August 2003 / Published online: 27 September 2003 (C) Springer-Verlag and AWI 2003

\begin{abstract}
We tagged individuals of the sea urchin Diadema antillarum (Philippi) around the island of Gran Canaria (The Canary Islands) during winter 2001-2002 using a new technique, consisting of the insertion of a hook fastened to a fishing line into the aboral pole (periproctal membrane). This allowed individual identification of tagged sea urchins. The goals were: (1) to quantify nocturnal movements and the homing behaviour of this echinoid on shallow rocky bottoms, and (2) to assess short term spatial and temporal variability of these movements. Tagged sea urchins displayed clear homing behaviour. The mean distance travelled at night was $3.7 \pm 1.2 \mathrm{~m}$ (range 1.0-5.1 m). Mean speed of nocturnal movement was $33 \pm 26 \mathrm{~cm} \mathrm{~h}^{-1}$ (range $5-110 \mathrm{~cm} \mathrm{~h}^{-1}$ ). We observed greater movement at midnight than at the beginning and the end of the night.
\end{abstract}

Keywords Diadema antillarum - Sea urchin - Tagging · Movements · The Canary Islands

\section{Introduction}

Marine resources have been decreasing in the coastal areas of the Canary Islands over the past decades, mainly due to the increase in fishing pressure. Therefore, removal of target fish-carnivorous fishes has led to the demographic explosion in the infralittoral rocky zones of the long-spined sea urchin Diadema antillarum (Philippi) (Aguilera et al. 1994; Casañas et al. 1998; Garrido et al. 2000; Herrera et al. 2000). D. antillarum is amphiAtlantic in distribution, and has been extensively studied throughout the Caribbean (Lawrence 1975; Lessios 1981,

\footnotetext{
Communicated by H.-D. Franke

F. Tuya $(\bowtie) \cdot J$. A. Martin · A. Luque

Biology Department, Faculty of Marine Sciences,

Universidad de Las Palmas de Gran Canaria,

35017 Las Palmas de Gran Canaria, The Canary Islands, Spain

e-mail: ftuya@yahoo.es

Tel.: +34-928-452836

Fax: +34-928-452922
}

1988; Carpenter 1984; Lessios et al. 1984, 2001; Levitan 1988, 1989, 1991).

Although the movement patterns of sea urchins vary between species (James 2000), Diadema, like many other sea urchin species, displays high nocturnal activity, feeding at night in the Caribbean (Randall et al. 1964; Odgen et al. 1973; Carpenter 1984) as well as in the Canary Islands (Casañas et al. 1998; Herrera et al. 2000). Nocturnal feeding behaviour may reduce or avoid predation by fish (Nelson and Vance 1979; Carpenter 1984; James 2000). Hence, predation pressure is suggested as being relevant in determining this behaviour in sea urchins throughout the world (Nelson and Vance 1979; Tertschnig 1989; Hagen and Mann 1994; Sala and Zabala 1996; Barnes and Crook 2001) and especially in the case of D. antillarum (Levitan and Genovese 1989). In addition, individuals of the genus Diadema display clear homing behaviour in America (Nelson and Vance 1979; Carpenter 1984).

Individuals of $D$. antillarum in the Canary archipelago shelter in caves, holes and crevices along shallow rocky reefs during the daytime. Individuals come out of their refuges and move around at night to graze on the surrounding algae within an unidentified radius (Casañas et al. 1998; Herrera et al. 2000). As a consequence of this feeding behaviour, this species has contributed to the decline of macroalgae populations throughout the Canary Islands (Aguilera et al. 1994; Casañas et al. 1998; Garrido et al. 2000; Herrera et al. 2000). In addition, the availability of food has been proposed as possible factor affecting the daily movement of sea urchins (Mattison et al. 1977; Russo 1979; Harrold and Reed 1985; Andrew and Stocker 1986; James 2000).

Although short-term (daily) movements of certain species of sea urchins such as Paracentrotus lividus in Europe (Dance 1987; Crook et al. 2000; Barnes and Crook 2001), Toxopneustes roseus in the Gulf of California (James 2000), Centrostephanus coronatus in the Pacific (Nelson and Vance 1979), Tripneustes ventricosus in the Virgin Islands (Tertschnig 1989), Tripneustes gratilla in Papua New Guinea (Nojima and Mukai 1985) 
and Strongylocentrotus droebachiensis in North America (Hagen 1996) have been studied using tagging techniques, there is only a single study by Carpenter (1984), in the Virgin Islands, on the nocturnal movements and homing behaviour of Diadema antillarum. However, this study lacks quantification of the movements. In our study on $D$. antillarum in the central East Atlantic Ocean, we used a new tagging technique and visually surveyed tagged individuals (1) to quantify the nocturnal movements and homing behaviour of this sea urchin, and (2) to asses their spatial and temporal short-term variability.

\section{Methods}

Selection of the technique

A preliminary study was carried out to check if any of the tagging techniques reported in the literature for echinoids (Sinclair 1959; Ebert 1965; Gamble 1965; Dix 1970; Odgen et al. 1973; Shepherd and Boudouresque 1979; Lewis 1980; Dance 1987; Crook et al. 2000; James 2000; Duggan and Miller 2001) could be applied to $D$. antillarum. Only techniques that did not require removal of the echinoid from its habitat were checked. We found that the techniques employed on short-spined urchins (e.g. Paracentrotus) could not be applied to a long-spined urchin, such as Diadema, mainly for the following reasons: (1) fragility of the Diadema spines, (2) great movement of these spines, and (3) the use of the pedicellariae and secondary spines to push tags up the spine. Mortality rates of up to $80 \%$ have been observed for tagging techniques that drill a hole in the test (Duggan and Miller 2001). We also tested the tagging procedure used by Carpenter (1984) on $D$. antillarum, but the urchins dropped the tagged spines on an alarmingly high number of occasions, even though in Carpenter's study this happened to fewer than $10 \%$ of the individuals.

Consequently, we selected a new tagging technique which consisted of the in situ introduction of a fishing hook (No. 11) with tweezers into the aboral pole (periproctal membrane) by a scuba diver. This hook was fastened to a fishing line $(\varphi=0.28 \mathrm{~mm}$, $\approx 10 \mathrm{~cm}$ long), which was attached to a cork buoy. This marker $(\approx 2 \times 2 \times 2 \mathrm{~cm})$ allowed for individual identification of tagged urchins. The tagging procedure usually took less than 20 seconds.

Preliminary tests were carried out to optimise this technique, as well as to assess the possible damage incurred by tagged urchins. The behaviour and travel distances of tagged individuals were simultaneously monitored and compared to non-tagged urchins by observers equipped with free-diving material, waterproof paper and metric tapes, over $24 \mathrm{~h}$ in an intertidal pool. The difference between individual travel distances was calculated by an independent sample $t$-test, as indicated by James (2000). Movement was not affected by tagging $(t=-0.152, d f=9, P=0.882)$. Furthermore, we selected a $10 \mathrm{~cm}$ length of a fishing line, as well as a $2 \times 2 \times 2 \mathrm{~cm}$ volume of the cork marker, as these dimensions minimise the possibility of individuals becoming entangled and thus modifying their behaviour.

\section{Nocturnal movements}

Thirty adult urchins [test diameter $>5.5 \mathrm{~cm}$; size class IV according to Casañas et al. (1998)] were individually tagged during daytime at three randomly selected crevices (i.e. tagging locations, ten tagged urchins per crevice) on rocky substrates in shallow water $(5-8 \mathrm{~m}$ depth) in Arinaga (Gran Canaria, the Canary Islands; $27^{\circ} 51.30^{\prime} \mathrm{N}$, $\left.15^{\circ} 23.00^{\prime} \mathrm{W}\right)$. The crevices were situated in an urchin-grazed barren area and were similar in shape and dimensions $(1-1.5 \mathrm{~m}$ long, 0.2-0.4 m wide, $0.3-0.5 \mathrm{~m}$ deep). Macroalgal beds were present on flat substrata 3 to $5 \mathrm{~m}$ away from the crevices.
Tagged urchins, which were feeding on the macroalgae surrounding the crevices at night, were located by three observers every $4 \mathrm{~h}$ at 19:30, 23:30, 3:30 and 7:30 by visual surveys using scuba and underwater lamps. The position of each individual in relation to the original tagging location was recorded on plastic boards with the help of an aquatic compass and a metric tape. We used a polar coordinate reference system ( $r$ and $\theta$ ) to locate and characterise the position of tagged individuals in the surroundings of each crevice (James 2000). Radius $r$ represents the distance from the tagging location, whereas $\theta$ represents the direction $\left( \pm 5^{\circ}\right)$, i.e. the angle between imaginary lines which link the tagging location and the actual position of the tagged urchin, respectively, to magnetic north.

Spatial movement patterns were analysed by plotting polar coordinates to estimate foraging paths and homing behaviour of tagged individuals (Carpenter 1984). Therefore, distances travelled between successive location times were calculated by means of basic trigonometric principles. Moreover, as the sum of four distances, we obtained an estimate of the total distance travelled per night. The calculated distances are underestimates, since we consider that individuals moved along a straight path between two successive points (Carpenter 1984). Furthermore, we calculated movement speeds for each tagged urchin between successive location times. To reduce the number of possible tagging artefacts, the coordinates were not used for analysis until $24 \mathrm{~h}$ after tagging (James 2000). At the end of the test, the sea urchins were removed.

The experiment was repeated three times (dates: 28 December 2001, 22 January 2002 and 17 February 2002) over the same three refuges (crevices) on days with similar moon phase and water movement. No significant differences in biological parameters (e.g. reproduction, recruitment) were detected for Diadema during this experimental period in the Canary archipelago (Casañas et al. 1998; Garrido et al. 1999, 2000). The 30 tagged sea urchins per test were randomly selected each time, to avoid problems of non-independence and pseudo-replication (sensu Hulbert 1984) of data.

\section{Data analysis}

The importance of the factors "refuge" (spatial variability, three refuges per assay) and "assay" (temporal variability, three assays for the overall study) for the mean distance travelled per refuge and assay was analysed by means of a two-way orthogonal ANOVA design (Underwood 1997). Both factors were treated as random.

A three-way orthogonal ANOVA design was carried out to test the effects of space (refuge), time (assay) and daily observation period $(15: 30-19: 30,19: 30-23: 30,23: 30-3: 30,3: 30-7: 30)$ on the average speed of movement. The first two factors were considered to be random, whereas the last one was established as fixed. The interpretation of interactions and a posteriori SNK tests were used to identify the effect of treatments for both ANOVA models, as indicated by Underwood (1997). The assumptions of normality and homoscedasticity were tested using the Kolgomorov-Smirnov and Levene tests, respectively. As no transformation rendered homogeneous variances, the level of significance was considered to be 0.01 instead of 0.05 (Underwood 1997). All the tests were carried out using the SPSS 10.0.3 statistical package.

\section{Results}

The estimated foraging paths with hourly positions of the six individuals tagged at refuge no. 1 in the assay carried out on 28 December 2001 are charted in Fig. 1. The results for other refuges and assays are similar and thus are not presented here. Tagged sea urchins displayed clear homing behaviour, with the individuals returning to the crevice (refuge) where they had been tagged. 

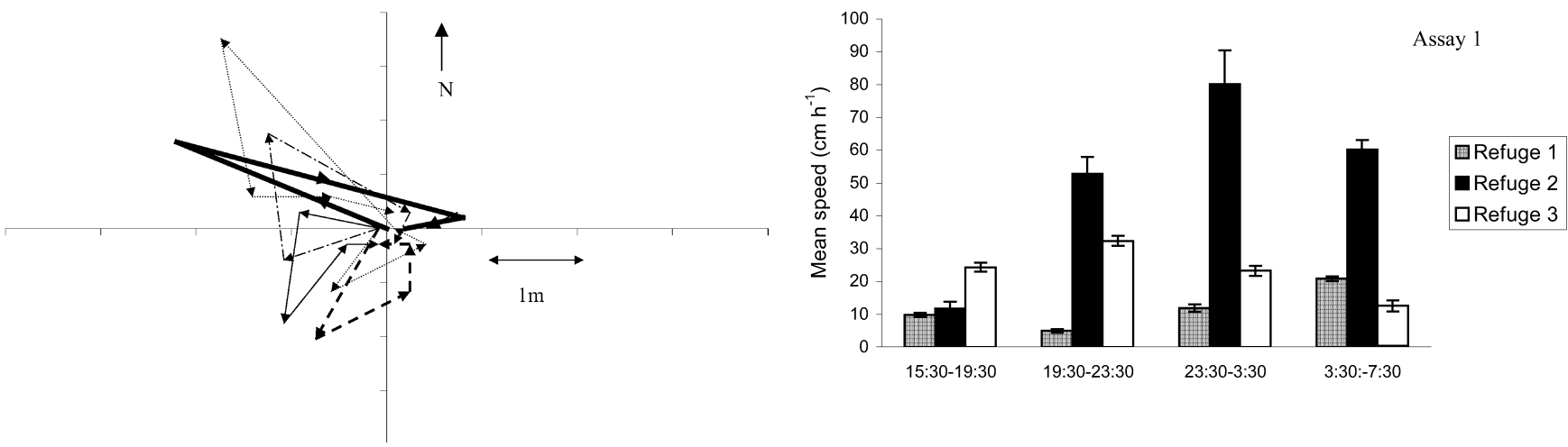

Fig. 1 Nocturnal foraging paths of six tagged D. antillarum from refuge 1 in the assay carried out on 28 December 2001, estimated from their positions recorded at $4 \mathrm{~h}$ intervals
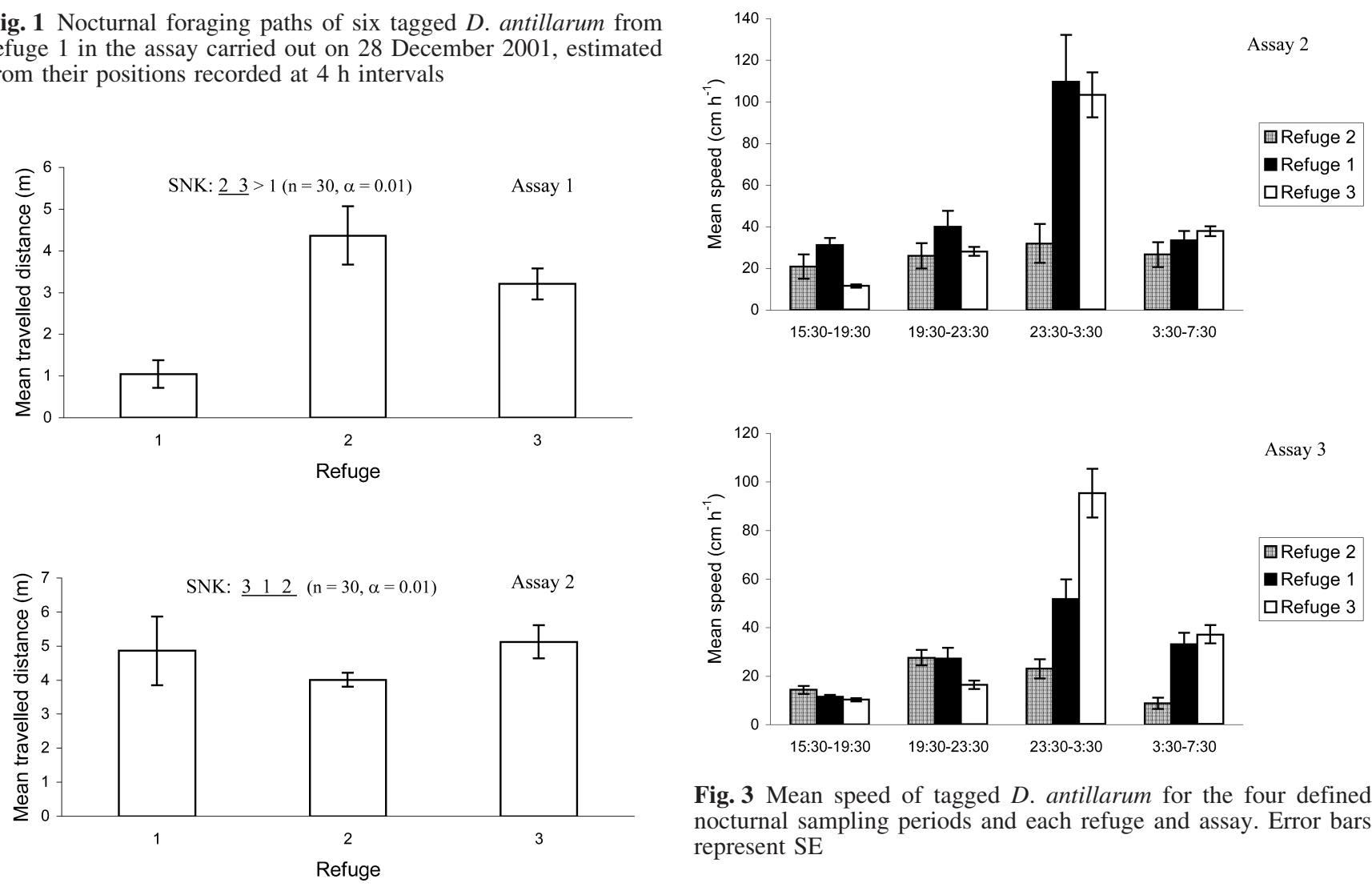

Fig. 3 Mean speed of tagged D. antillarum for the four defined nocturnal sampling periods and each refuge and assay. Error bars represent $\mathrm{SE}$

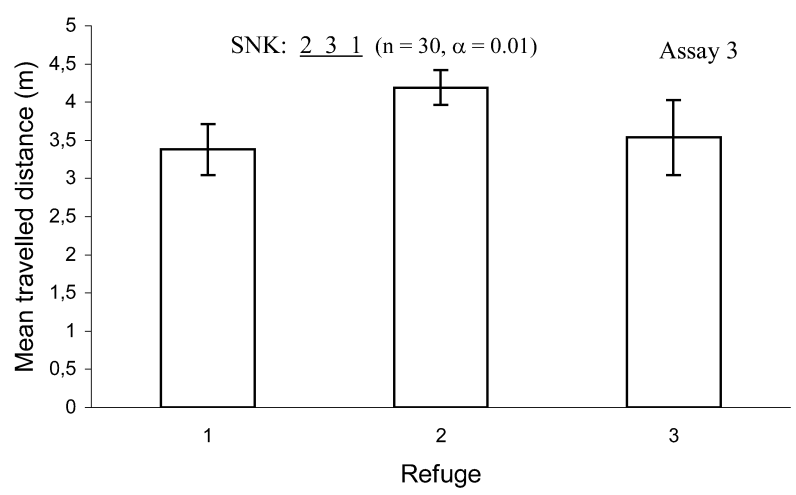

Fig. 2 Mean distances travelled during the night by tagged individuals of $D$. antillarum $(n=10)$ for each refuge and assay. Error bars represent SE

The mean distance travelled per assay by a tagged individual during the night fluctuated between 1.0 and $5.1 \mathrm{~m}$ throughout the study (Fig. 2). For the overall study, we obtained a mean value of $3.7 \pm 1.2 \mathrm{~m}(n=90)$. Mean speed of nocturnal movement varied between 5 and $110 \mathrm{~cm} \mathrm{~h}^{-1}$ (Fig. 3), with a mean value of $33 \pm 26 \mathrm{~cm} \mathrm{~h}^{-1}$.

The urchins' pattern of nocturnal movement (mean travelled distance and mean speed) was influenced by all considered experimental factors (Tables 1,2 ). The most complex effect was a significant three-factor interaction involving refuge, assay and sampling time $(P<0.01$, Table 2). Moreover, the factors "refuge" and "assay" were involved in a significant two-factor interaction for both ANOVA models $(\mathrm{A} \times \mathrm{B} ; P \approx 0.01$ for the variable "mean distance travelled" (Table 1), and $P<0.01$ for the variable "speed" (Table 2). However, neither the experimental factor "refuge", nor the factor "assay", had 
Table 1 Results of two-way orthogonal ANOVA on the effects of space (refuge) and time (assay) on total mean nocturnal distance travelled by tagged individuals of Diadema antillarum

\begin{tabular}{lrrcl}
\hline Source of variation & $d f$ & \multicolumn{1}{l}{ SS } & \multicolumn{1}{l}{ MS } & $F$ \\
\hline A (refuge) & 2 & 0.345 & 0.173 & 0.837 \\
B (assay) & 2 & 0.325 & 0.163 & 0.789 \\
A $\times$ B & 4 & 0.824 & 0206 & $3.157^{*}$ \\
Error & 81 & 5.287 & 0.0652 & \\
\hline
\end{tabular}

$* P<0.05$

Table 2 Results of three-way orthogonal ANOVA on the effects of space (refuge), time (assay), and nocturnal observation period (sampling period) on migratory speed of tagged individuals of $D$. antillarum

\begin{tabular}{lrcll}
\hline Source of variation & $d f$ & \multicolumn{1}{l}{ SS } & MS & $F$ \\
\hline A (refuge) & 2 & 6.22 & 3.11 & 3.073 \\
B (assay) & 2 & 1.339 & 0.67 & 0.662 \\
C (sampling time) & 3 & 6.79 & & No test \\
A $\times$ B & 4 & 4.048 & 1.012 & $2.691 * *$ \\
A C & 6 & 3.232 & 0.539 & 0.51 \\
B $\times$ C & 6 & 2.116 & 0.353 & 0.334 \\
A $\times$ B $\times$ C & 12 & 12.659 & 1.055 & $2.808^{* *}$ \\
Error & 324 & 121.074 & 0.376 & \\
\hline
\end{tabular}

$* * P<0.01$

significant main factor effects $(P>0.05$, Tables 1,2$)$. The a posteriori SNK test for the variable "mean speed" over the different levels of the factor "sampling time" showed that,

\begin{tabular}{llll}
$\underline{23: 30-3: 30} \quad 19: 30-23: 30$ & $3: 30-7: 30$ & $15: 30-19: 30$ \\
\hline$\overline{0.01, n=90)}$ & &
\end{tabular}

$(\alpha=0.01, n=90)$

Consequently, tagged $D$. antillarum individuals showed periods of different speed of movement during the night, with greater values at midnight than during marginal periods (the beginning and the end of the night) (Fig. 3).

\section{Discussion}

Tagging technique

Sea urchins are easy to follow in indoor experiments (e.g. Hay et al. 1986; Hagen and Mann 1994). However, at present, there is no universal tagging procedure for sea urchins in the wild. The various tagging methods all have advantages and disadvantages (Dance 1987). Tagging techniques depend upon sea urchin morphology and, hence, spine length. Although external tags or marks (Sinclair 1959; Gamble 1965; Dix 1970; Shepherd and Boudouresque 1979; Lewis 1980; Carpenter 1984; James 2000) can effectively be employed to study short-term movements, they have not proved to be worthy on a longterm basis, as they are lost more or less rapidly by the urchins (Dance 1987). Authors who anchored tags in a hole in the test (Dix 1970; Nelson and Vance 1979; Duggan and Miller 2001) found that the hole did not recalcify and found up to $50 \%$ mortality. Therefore, some papers (Ebert 1965; Dix 1970) have suggested using tags pushed into the test. On the other hand, techniques such as using poultry and rod tags (Duggan and Miller 2001) require tagged urchins to be sacrificed and the tag removed to identify individuals.

The technique employed in our study is cheap, quick and easy for experienced scuba divers. The procedure is carried out in situ and does not require the removal of the urchins from their habitat. Furthermore, the technique has been effective, as a high percentage $(85.5 \%)$ of tagged individuals could be followed during the nocturnal assays. However, a problem that we have not as yet evaluated is the possible attraction of the inserted tags for predators. As Dance (1987) pointed out, the effect of tagging on short-term activity is difficult to determine, because nontagged individuals are not easy to follow at night in the field. Although no flight response or podia movement was observed immediately after tagging, it is difficult to provide evidence of the damage caused by tagging to the behaviour of sea urchins, such as has been considered in the many tagging and marking studies which exist in the literature (Sinclair 1959; Gamble 1965; Shepherd and Boudouresque 1979; Lewis 1980; Dance 1987). However, we did not observe significant differences between tagged and non-tagged urchins in the preliminary tests. Therefore, our technique can be applied effectively to mark individuals of the long-spined sea urchin $D$. antillarum and to study their short-term (daily) migrations.

\section{General results}

D. antillarum moves around to graze on the rocky substratum during the night, removing attached algal filaments and algal crusts (Carpenter 1984). The maximum mean speed registered in our study $\left(110 \mathrm{~cm} \mathrm{~h}^{-1}\right)$ was higher than the maximum value obtained by Dance (1987) for grazing of $P$. lividus in the Mediterranean $\left(40 \mathrm{~cm} \mathrm{~h}^{-1}\right)$. Likewise, the average speed observed in our study $(33 \mathrm{~cm}$ $\mathrm{h}^{-1}$ ) was superior to that registered by James (2000) for the echinoid Toxopneustes roseus at two sites (6.6 and $11.7 \mathrm{~cm} \mathrm{~h}^{-1}$ ) in the surroundings of the Gulf of California, but similar to that recorded for the sea urchin Tripneustes ventricosus in a tropical patch reef $\left(26 \mathrm{~cm} \mathrm{~h}^{-1}\right.$; Tertschnig 1989). In addition, the average distance travelled per day in our study $(3.7 \mathrm{~m})$ was also superior to the average distances recorded for P. lividus (0.5 m; Dance 1987), C. coronatus (1.2 m; Nelson and Vance 1979), and Toxopneustes roseus (1.65 and $2.49 \mathrm{~m}$; James 2000), but similar to those observed for the sea urchin Tripneustes ventricosus in a tropical patch reef $(3.7 \mathrm{~m}$; Tertschnig 1989). Daily average distances crossed by $S$. droebachiensis located in the vicinity of kelp forests was found to be influenced by food availability $(7.5 \mathrm{~cm}$ near to the kelp forest in contrast to $54 \mathrm{~cm}$ far from the kelp forest; Mattison et al. 1977). Evechinus chloroticus moved 1.2 and $0.5 \mathrm{~m}$, respectively, in the presence/absence of drift algae (Andrew and Stocker 1986). 
Several authors (Aguilera et al. 1994; Casañas et al. 1998; Garrido et al. 2000; Herrera et al. 2000) have observed and commented upon the decline of macroalgae populations throughout the Canary Islands over the last few decades as an indirect consequence of overexploitation of coastal fishery resources, which may have favoured the demographic explosion of echinoids, such as $D$. antillarum on the shallow rocky bottoms, through removal of sea urchin predators (Hay 1984; Carpenter 1984; McClanahan and Muthiga 1988; McClanahan and Shafir 1990; McClanahan et al. 1996). Thus, there is an inverse relationship between food availability (algae) and movement in many sea urchins (Mattison et al. 1977; Russo 1979; Harrold and Reed 1985; Andrew and Stocker 1986), which may explain the large distances travelled by D. antillarum at Arinaga (Gran Canaria) in comparison to other echinoid species. Besides, the food resources (macroalgae) become less abundant when sea urchin density increases, possibly favouring the use of a wide foraging range as has been observed in $D$. antillarum in the Canary archipelago (Tuya et al. 2001).

D. antillarum displays clear homing behaviour in Gran Canaria. Homing, or "crevice fidelity", refers in particular to the repeated occupation of the same refuge, as an adaptive process (Carpenter 1984). The majority of individuals return to the crevice (refuge) where they started their nightly movement to graze on the surrounding vegetal beds. This is not surprising, since such patterns have already been recorded for the genus Diadema in America (Nelson and Vance 1979; Carpenter 1984). Although these authors suggested that predator abundance influences the daily activity and homing behaviour of Diadema individuals, our study can not address this hypothesis, since no predation pressure was measured. However, such patterns have not been observed for other sea urchin species such as Toxopneustes roseus (James 2000) or P. lividus (Dance 1987). Moreover, the daily movements of these two species are not dependent on food abundance. Daily migrations of $P$. lividus occur mainly to avoid surge (Dance 1987), while the movements of Toxopneustes roseus may occur to prevent over-grazing, as well as avoid turbulence (James 2000). Therefore, the direction of the urchins' movement is not random. Although the direction of tagged Diadema individuals in Gran Canaria varied greatly over the three assays carried out, movement is not random, since urchins generally trace out an irregular loop to return to their refuge. This fact is corroborated by the lack of significance of the two main effects in the ANOVA designs. This pattern was also recognized by Carpenter (1984), who found that sea urchins such as Diadema avoid previously grazed areas on successive nights.

We have detected significant changes in the average speed of movement over the nocturnal period. A maximum was observed at midnight, while minimum values coincided with the beginning and the end of the night. In contrast, Dance (1987) observed high activity at sunset in Paracentrotus, which remained constant throughout the rest of the night. This may be explained by the lack of homing behaviour, or by the assumption that food availability does not influence the movements of this species.

The migratory and homing behaviour of echinoids is influenced by a range of abiotic and biotic factors (e.g. Carpenter 1984; Dance 1987; James 2000; Barnes and Crook 2001) and may differ between species (James 2000). Consequently, future research into the nocturnal movements of $D$. antillarum in the Canary archipelago should include the effects of factors that we have not yet evaluated: moon phase, size/age, predator pressure, water turbulence and availability of food and refuges.

Acknowledgements We thank all the students who helped us with the field work. Our thanks also go to Margaret Hart for helping with English reviewing and Arturo Boyra for ideas and comments on the tagging technique. The authors hereby declare that the experiments comply with the current laws of Spain.

\section{References}

Aguilera F, Brito A, Castilla C, Díaz A, Fdez-Palacios JM, Rodríguez A, Sabaté F, Sánchez J (1994) Canarias: Economía, Ecología y Medio Ambiente. Francisco Lemus Edit, Islas Canarias

Andrew NL, Stocker LJ (1986) Dispersion and plagokinesis in the equinoid Evechinus chloroticus (Val). J Exp Mar Biol Ecol 100:11-23

Barnes DKA, Crook AC (2001) Quantifying behavioural determinants of the coastal European sea urchin Paracentrotus lividus. Mar Biol 138:1205-1212

Carpenter RC (1984) Predator and population density control of homing behaviour in the Caribbean equinoid Diadema antillarum. Mar Biol 82:101-108

Casañas A, Hanek-Larsen H, Haroun R (1998) Developmental stages of blanquizal due to hervivory by the sea urchin Diadema antillarum Philippi in the Canary Islands. Bol Mus Munic Funchal 5:139-146

Crook A, Long M, Barnes DKA (2000) Quantifying daily migration in the sea urchin Paracentrotus lividus. J Mar Biol Assoc UK 80:177-178

Dance C (1987) Patterns of activity of the sea urchin Paracentrotus lividus in the Bay of Port-Cross (Var, France, Mediterranean). PSZNI Mar Ecol 8:131-142

Dix TG (1970) Biology of Evechinus chloroticus (Echinoidea, Echinometridae) from different localities. NZ J Mar Freshw Res 4:267-277

Duggan RE, Miller RJ (2001) External and internal tags for the green sea urchin. J Exp Mar Biol Ecol 258:115-122

Ebert TA (1965) A technique for the individual marking of sea urchin. Ecology 46:193-194

Gamble JC (1965) Some observations of the behaviour of two regular equinoids. In: Rapp, Symp, Lythgoe, Woods (eds). Underwater Association, Malta

Garrido MJ, Herrera R, Haroun R (1999) Structure and dynamics of marine macroinvertebrate communities at Canarian artificial reefs (Central East Atlantic Ocean). Proceedings of the 7th CARAH, pp114-120

Garrido MJ, Haroun RJ, Lessios HA (2000) Annual reproductive periodicity of the sea urchin Diadema antillarum Philippi in the Canary Islands. Bull Mar Sci 67:919-996

Hagen NT (1996) Tagging sea urchins: a new technique for individual identification. Aquaculture 139:271-284

Hagen NT, Mann KH (1994) Experimental analysis of factors influencing the aggregating behaviour of the green sea urchin Strongylocentrotus droebachiensis. J Exp Mar Biol Ecol 176:107-126 
Harrold C, Reed DC (1985) Food availability, sea urchin grazing, and kelp forest community structure. Ecology 66:1160-1169

Hay ME (1984) Patterns of fish and urchin grazing on Caribbean coral reefs: are previous results typical? Ecology 65:446-454

Hay ME, Lee RR, Guieb RA (1986) Food preference and chemotaxis in the sea urchin Arbacia punctulata (Lamarck). J Exp Mar Biol Ecol 96:147-143

Herrera R, Garrido M, Moro Abad L (2000) Pierde biodiversidad el medio marino Canario? Los blanquizales y el erizo Diadema antillarum. Medio ambiente en Canarias 17:22-25

Hulbert SH (1984) Pseudoreplication and the design of ecological field experiments. Ecol Monogr 54:187-211

James DW (2000) Diet, movement, and covering behaviour of the sea urchin Toxopneustes roseus in rhodolith beds in the Gulf of California, Mexico. Mar Biol 137:913-923

Lawrence JM (1975) On the relationships between marine plants and sea urchins. Oceanogr Mar Biol Annu Rev 13: 213-286

Lessios HA (1981) Reproductive periodicity of the echinoids Diadema and Echinodermata on the two coast of Panama. J Exp Mar Biol Ecol 50:47-61

Lessios HA (1988) Population dynamics of Diadema antillarum (Echinodermata: echinoidea) following the mass mortality in Panama. Mar Biol 99:515-526

Lessios HA, Robertson DR, Dubit DJ (1984) Spread of Diadema mass mortality through the Caribbean. Science 226:335-337

Lessios HA, Kessing BD, Pearse JS (2001) Population structure and speciation in tropical seas: global phylogeography of the sea urchin Diadema. Evolution 55: 955-975

Levitan DR (1988) Density-dependent size regulation and negative growth in the sea urchin Diadema antillarum. Oecologia 76:627-629

Levitan DR (1989) Density-dependent size regulation in Diadema antillarum: effects on fecundity and survivorship. Ecology 70:1414-1424

Levitan DR (1991) Skeletal changes in the test and jaws of the sea urchin Diadema antillarum in response to food limitation. Mar Biol 111:431-435

Levitan DR, Genovese SJ (1989) Substratum-dependent predatorprey dynamics: patch reefs as refuges from gastropod predation. J Exp Mar Biol Ecol 130:111-118

Lewis GA (1980) Geotactic movements following disturbance in the European sea urchin Echinus esculentus (Echinodermata, Echinoidea). Prog Underw Sci 5:171-186

Mattison JE, Trent JD, Shanks AL, Akin TB, Pearse JS (1977) Movement and feeding activity of red sea urchin Strongylocentrotus droebachiensis adjacent to a kelp forest. Mar Biol $39: 25-30$
McClanahan TR, Muthiga NA (1988) Changes in Kenyan coral reefs. Community structure and function due to exploitation. Hydrobiologia 166:269-276

McClanahan TR, Shafir SH (1990) Causes and consequences of sea urchin abundance and diversity in Kenyan coral reefs. Oecologia 83:362-370

McClanahan TR, Kamukuru AT, Muthiga NA, Gilagabher M, Obura D (1996) Effect of sea urchin reductions on algae, coral and fish populations. Conserv Biol 10:136-154

Nelson BV, Vance RR (1979) Diel foraging patterns of the sea urchin Centrostephanus coronatus as a predator avoidance strategy. Mar Biol 51:251-258

Nojima S, Mukai H (1985) A preliminary report on the distribution pattern, daily activity and moving pattern of a seagrass grazer, Tripneustes gratilla (L.) (Echinodermata, Echinoidea) in Papua New Guinea seagrass beds. Spec. Publ Mukaishima Mar Biol Stn, pp173-183

Odgen JC, Abbot DP, Abbot I (1973) Studies on the activity and food of the echinoid Diadema antillarum Philippi on a West Indian patch reef. Spec. Publ. 2. West Indies Lab. Fairleigh Dickinson University, Ste Croix, Virgin Islands

Randall JE, Schroeder RE, Stark WA (1964) Notes on the biology of the equinoid Diadema antillarum. Caribb J Sci 4:421-433

Russo AR (1979) Dispersion and food differences between two populations of the sea urchin Strongylocentrotus franciscanus. J Biogeogr 6:407-414

Sala E, Zabala M (1996) Fish predation and the structure of the sea urchin Paracentrotus lividus population in the NW Mediterranean. Mar Ecol Prog Ser 140:71-81

Shepherd A, Boudouresque CF (1979) A preliminary note on the movement of the sea urchin Paracentrotus lividus. Trav Sci Parc Natio Port-Cross 5:155-158

Sinclair AN (1959) Observation on the behaviour of sea urchins. Aust Mus Mag 13:3-8

Tertschnig WP (1989) Diel activity patterns and foraging dynamics of the sea urchin Tripneustes ventricosus in a tropical seagrass community and a reef environment (Virgin Islands). PSZNI Mar Ecol 10:3-21

Tuya F, Martin JA, Reuss GM, Luque A (2001) Feeding preferences of the sea urchin Diadema antillarum in Gran Canaria Island (Central East Atlantic Ocean). J Mar Biol Assoc UK 81:1-5

Underwood AJ (1997) Experiments in ecology: their logical design and interpretation using analysis of variance. Cambridge University Press, Cambridge 